\title{
EEN BEZOEK AAN HET MUSEUM IN COSTA RICA
}

\author{
OUDHEIDKUNDIGE VERWANTSCHAP TUSSEN \\ MIDDEN-AMERIKA EN SURINAME
}

Ik heb het geluk gehad het 33ste Internationaal Americanistencongres te San José in Costa Rica, in juli r958, te mogen bijwonen.

Twee gebouwen der universiteit werden door de Regering hiertoe afgestaan. Een week lang traden in de verschillende lokalen gelijktijdig geleerden op en hielden hun voordracht, geleerden van 40 verschillende nationaliteiten, voordrachten over archeologie, etnologie, linguistiek, geschiedenis, enz.; elk onderwerp echter dat zij bespraken betrekking hebbend op Amerika, Noord-, Zuid- of Midden-Amerika.

Je doet een keuze: waar iets van je gading besproken wordt, ga je luisteren. Zo schiet er tijd over, niet alles interesseert je.

Maar dan is er het Museo Nacional met zijn schat van opgegraven voorwerpen uit het oud verleden dat je roept, dringend uitnodigt. $\mathrm{Al}$ die tentoongestelde voorwerpen, kunstprodukten en ordinaire huiselijke dingen, van godsdienstige of profane aard, afkomstig van Costa Rica en omliggende landen, uit eeuwen en eeuwen die voorbij zijn, houden hier in de zalen ook hun bijeenkomst, hun congres. Elk object heeft het zijne te vertellen, elk houdt zijn voordracht.

Interessant voor hem die weet te verstaan.

Ik heb herhaaldelijk het museum bezocht. Een fors gebouw, eertijds een fort. De zalen zijn fris, maar ook donker. Zonder de lampen zag je midden op de dag van menige uitstalling niet veel.

De Costarikeinen zorgen er wel voor de kennis van hun oude cultuur door middel van hun cultuurobjecten de mensen van de huidige tijd bij te brengen. Ze beginnen al met de kinderen. Elke keer dat je er kwam, stond in deze of gene afdeling een groep schoolkinderen onder leiding van onderwijzers. Er was ook iemand die verklaring gaf. Voor volwassenen, inwoner en vreemdeling, heeft het museum zijn publikaties.

$\mathrm{Na}$ de reorganisatie in I953, waardoor het museum onder het Ministerio de Educación Pública ressorteerde, verscheen de eerste 
EEN BEZOEK AAN HET MUSEUM IN COSTA RICA 5I

publikatie: El Jade precolombino de Costa Rica door Carlos Balser. In het voorwoord heet het o.a.: "De administratie van het museum heeft het plan opgevat geleidelijk een serie verhandelingen uit te geven, betrekking hebbend op de collecties en eventuele tentoonstellingen van het museum". En: "Het is ons doel op populaire wijze te belichten sommige details van ons doen en laten, hetzij uit voor-columbiaanse tijden, hetzij uit het niet zo verre verleden, hetzij zelfs uit het heden". En verder: "Wij wensen door deze diepere, vollediger uiteenzetting de héle wereld gelegenheid te geven onze cultuur te leren kennen".

Is men die belofte nagekomen?

Welke en hoevele publikaties na de eerste van Carlos Balser gevolgd zijn, weet ik niet. Maar dit jaar, I958, verschenen er minstens twee. Tussen de uitgaven van r 953 en die van 1958 is groot verschil. Die van 1953 is eenvoudig, alhoewel de foto's talrijk zijn en afgedrukt op glad papier. Maar die van I958 zijn luxe-uitgaven. Groot formaat. In een der twee zelfs kleurafdrukken. Het 33ste Americanistencongres, dat dit jaar in Costa Rica gehouden zou worden (en ook gehouden is), heeft tot die luxe-uitgaven aanleiding gegeven.

Genoemde luxe-uitgaven zijn: Introduction to the Archaeology of Costa Rica door Doris Stone, de voorzitster van het 33ste internationale congres van Americanisten en The Aboriginal Metalwork in the Isthmian Region of America door Doris Stone \& Carlos Balser.

Deze drie publikaties bespreken alle in het museum uitgestalde voorwerpen, die naar de streek van het land waar ze gevonden werden verdeeld worden in twee hoofdgroepen: die van het hoogland en die van het laagland.

In het laagland, het Karaîbisch gebied (om de Karaîben die ook in de Guyana's wonen spreekt dit gebied je het meest aan), is om haar archeologische vondsten het meest beroemd de streek genaamd de 'Linea Vieja'. Uit die vondsten blijkt dat Linea Vieja al vóór Columbus' tijd een handel bezat, die zich uitstrekte tot ver over de huidige politieke grenzen. Het had relaties o.a. naar het Zuiden toe met Panama, Columbia en de Antillen. Voorwerpen in die landen gevonden, vindt men ook hier. Linea Vieja wordt dan ook vergeleken met een bazaar. De archeologen noemen de streek: het tentoonstellingsgebied van Costa Rica.

Strekte de invloed van Costa Rica zich ook uit tot de Guyana's, inzonderheid tot Suriname? 
Het is niet onredelijk zulks te veronderstellen.

De 'Linea Vieja' is een streek van zware regenval en vele rivieren. Woonplaatsen, graven, handelswegen moesten beschermd worden tegen het water. Om haar terpen is daarom de streek opvallend. Die terpen hebben aan haar voet stenen als afweer tegen erosie. In Las Mercedes is zelfs een hele groep van terpen opgeworpen in een 'swamp'. De muur die de terpen omringt, heeft dan ook meer lagen steen. Het binnenste is opgevuld met zand. De terpen zijn onderling en met een waterput verbonden door een keisteenweg; 50 tot 60 meter van de woningen is het kerkhof.

Ook elders in Costa Rica, meer naar het Zuiden toe tegen Panama aan, komen die bewoonde terpen voor, zo in het deltagebied van de Diquisrivier en in het gebied noordelijk van de Potrero Grande.

$\mathrm{Nu} . .$. volgens de recente opgravingen van Dr. Geijskes op de zogenaamde Hertenrits nabij Wageningen, woonden er in de oude tijd in Suriname ook Indianen midden in het moeras. Ook zij maakten verhogingen, terpen. Vreemd doet het ons mensen van deze tijd aan. Heel gewoon echter schijnt 'het terpen opwerpen' eertijds geweest te zijn in die gebieden waar het water overvloedig was. Uitwisseling van ideeën schijnt er dus te zijn geweest, gelijkheid o.a. in woningbouw was er zeer zeker.

De voorwerpen van het museum worden naar gelang het 'materiaal', waaruit ze vervaardigd zijn, tot 4 klassen teruggebracht. De grondstof is: I) (gebakken) klei; 2) vulcanisch gesteente; 3) edel- en sierstenen; 4) metaal (vooral goud).

Die voorwerpen beschouwend, valt onmiddellijk de onmetelijk grote afstand op tussen de ontwikkeling van de eertijdse GuyanaKaraīb en de Karaīb uit noordelijker landen, zeg van Costa Rica. Let alleen maar op het materiaal, dat men gebruikte! De Guyana-man schijnt enkel te hebben gekend klei, hout, gebeente en tanden tot het vervaardigen van hetzij het noodzakelijke huisraad, hetzij vermaaks- of versieringsvoorwerpen. Vulcanische steen of andere steen, edelsteen, goud schijnen hem onbekend.

Een greep doe ik uit al die voorwerpen, om de lezer enig idee ervan te geven.

I) VOORWERPEN VAN VULCANISCHE STEEN

Staande beelden: afmeting vanaf enkele centimeters tot I,5I meter hoogte. De man draagt een stenen bijl; een menselijk hoofd, krijgstrofee hangt 
aan zijn gordel. Of een zittende figuur, de armen gevouwen op de opgetrokken knieën in contemplatieve houding. De laatste figuur wordt met medicijnman (piaiman) aangeduid. Soms zijn op de mannelijke figuren ornamenten aangebracht: halssnoeren, armbanden, enz. Of het haar is kunstig opgemaakt. De vrouwelijke figuren dragen gewoonlijk geen sieraad. Met elk van haar beide handen houdt zij éen van haar borsten op.

Offerstenen: Ronde steenblokken, rijkelijk met inschriften voorzien, de bovenzijde geëffend, eer min of meer uitgehold voor ontvangst van het slachtoffer. Het blok heeft een diep-uitgekapte goot voor afvoer van het bloed.

Grafstenen: Vlakke stenen platen tot 2 meter lang. Alle vier de kanten van de plaat hebben een rand van menselijke koppen in hoog reliëf als versiering.

Maalstenen: Tot 3/4 meter hoogte. Het onderstuk stelt soms een gestyleerde poema of aap voor; het bovenstuk - het vlak, waarop men het produkt (aardvrucht, cacao, mais, enz.) tot moes of meel wreef - is effen of gerimpeld, met of zonder rand, naar gelang het produkt vorderde.

Mortieren: De handvaten van het mortier, het handvat van de stamper, stellen vaak een dierenkop voor.

Maskers: Een stenen masker (ook in goud komen de maskers voor) werd soms de dode in het graf over het gelaat gelegd.

Bijlen: Dezelfde soort stenen bijl als ook in Suriname overvloedig gevonden wordt.

Fluitjes en okarina's: Er zijn fluitjes met 4 of 6 gaatjes, waaruit men 12 of 18 tonen kan halen.

2) VOORWERPEN VAN EDEL- EN SIERSTENEN

De edel- en sierstenen van Costa Rica zijn: groene smaragd, paarse amethist, melkwitte opaal, agaat, turkoois, jadeiet en nefriet, lazuursteen, enz.

De edel- of siersteenvoorwerpen stellen voor: menselijke figuren, dieren (kikker, kruipend gedierte, vogels, o.a. arend, guyaké en vissen), kralen en staafjes, al of niet met insnijdingen of reliëfwerk versierd. Fluitjes zelfs komen voor.

Hoe en waar op het lichaam de edelsteenornamenten gedragen werden, leren ons de stenen of houten voorstellingen van hun afgoden. Meestal treden zij op als hangers op de borst, aan de neus, aan het oor, zelden om de polsen. De ornamenten van groter afmeting waren uitsluitend voor de afgoden.

Opvallend is, dat de meeste edelsteenornamenten voorkomen in stenenbijl-vorm. Over deze ornamenten het volgende: Op bepaalde tijden, verband houdend met de maanstand, werden mensen aan de goden geofferd (40.00o per jaar). Om die offers, als de ure van offeren kwam, bij de hand te hebben, trok men geregeld ten strijd. Met de scherpe stenen bijl opende men de borst van het slachtoffer. Men nam vervolgens het hartebloed, het enig voor de goden passend voedsel. De stenen bijl werd in edelsteen als sieraad nagemaakt, in kleinere afmeting natuurlijk. Geleidelijk kwamen er ornamenten op. Terwijl de uiterlijke vorm van 'bijl' bleef, nam de ornamentiek toe. De oorspronkelijke idee van 'bijl', voornaam snijwerktuig bij de godsdienstoefening, verdween, maar het 'godsdienstige' van de bijl bleef aan het ornament hangen. 
De bijlen en bijltjes werden symbolische amuletten. Speciale amuletten voor speciale groepen van mensen: edelen, priesters, krijgers, voor elk individu, heel kleine bijltjes bijv. voor pasgeborenen.

De middelen, om de edel- en sierstenen te bewerken, waren allerprimitiefst: water, zand of steengruis, de huidenzaag, de boog-boor.

De $z a a g$ is niets anders dan een stuk tot koord gedraaide ruwe huid. Dit koord werd met beide blote handen als een 'zaag' voortdurend op en neer gehaald. Steeds op dezelfde plek van de steen natuurlijk. En met constante toevoeging van water en gruis.

De boog-boor - ook al zo'n primitief instrument - was voor mij een openbaring. Ze verklaart, hoe eertijds onze Indianen de harde 'dierentanden' doorboord kregen, om ze tot halssnoeren aaneen te kunnen rijgen. Het instrument lag nu voor me. Prof. W. Saake uit São Paulo (Brazilië) verklaarde mij het gebruik ervan. De boog-boor was in de oudheid over de beide Amerika's verspreid. Zelfs de Eskimo's in het hoge Noorden kenden ze. Aldus weer de professor. Ik spreek over deze boor verderop, waar ik alle mij bekende primitieve werktuigen, eens of nu nog in gebruik in Suriname, voor de duidelijkheid achtereenvolgens opsom en (in het kort) bespreek.

Het polijsten geschiedde middels een harde steen of een harde op bamboe lijkende stok en wilde bijenwas.

\section{3) VOORWERPEN VAN METAAL}

Het metaal, dat in de pre-columbiaanse tijd in Midden-Amerika tot sieraden werd verwerkt, was goud. Dit was hoofdzakelijk afkomstig van pepieten. Meestal werd het goud gemengd met koper en soms met een klein percentage zilver. Dit mengsel wordt doorgaans 'tumbaga' genoemd, afgeleid van het maleise woord 'tembaga' dat koper betekent.

Toen Columbus $8 \beta$ zijn vierde en laatste reis in Costa Rica voet aan wal zette, zag hij vele van die gouden sieraden. En dit was voor hem een aanleiding het land 'Costa Rica' (= Rijke Kust) te noemen.

Linea Vieja is bekend om kleinere voorwerpen, maar van het allerhoogste goudgehalte. Die voorwerpen stellen wederom voor: menselijke figuren (hoofdmannen), vogels, kikkers, enz. Veel voorkomend, en vandaar zeer bekend, zijn de 'arenden'. Het gouden sieraad stelt een vogel voor met uitgespreide vleugels. Maar het is de arend niet, het is de aasgier.

De meest voorkomende methode, om genoemde beeldjes te fabriceren, was wat men noemt 'the lost wax process', een der oudste in de wereld bekende methodes om beelden te gieten. Bijenwas en hars werden gemengd en tot het gewenste beeld geboetseerd. Dit wassen beeld werd omgeven met een mantel van klei en hars, waarin afvoergaten waren aangebracht. Het geheel werd nu verhit. Het wassen beeld smolt en liep door de afvoergoten weg. In de achtergebleven holte werd dan het gesmolten goud gegoten. Het vuur, dat het goud in een pot smelten moest, werd zonder onderbreken opgejaagd door vele mannen, die door lange pijpen wind toebliezen.

4) VOORWERPEN VAN GEBAKKEN KLEI

Hebben de oude Guyana-Karaïben vermoedelijk al niet gewerkt in steen, edelgesteente en goud, op het gebied van pottenbakkerij stonden ze mogelijk hun man. 
Is er connectie tussen Guyana en Midden-Amerika?

Vergelijken we de 'hedendaagse' produkten onzer Indianen met de 'prehistorische' te Costa Rica, dan spreekt het vanzelf dat de bewijzen van onderlinge relatie, van mogelijke verwantschap, maar zeer mager kunnen zijn. Waar men vanuit de civilisatie voorwerpen - zowel nuttige als fraaie - relatief gemakkelijk krijgen kon, nam geleidelijk de inspanning, om met primitieve middelen iets kunstigs te fabriceren, af. Toch vindt men wel iets.

Onder de in Costa Rica opgegraven 'oude' voorwerpen komen ook de kruikjes voor, twee of drie in getal, die onderling met gebakken banden of hengsels verenigd zijn. Onze Karaïben en Arrowakken bakken ze 'hedendaags' nog. De Karaïben noemen ze: 'asè-munisi' (= van hetzelfde bloed). Wij zouden ze tweeling, drieling noemen. Dat soort kruikjes schijnt in de oudheid overal verspreid te zijn geweest. Het land van oorsprong moet Peru zijn.

Ik zag onlangs nog langs de spoorbaan een door een onzer Indiaansen geboetseerde pot, die op een van zijn flanken een gestyleerde mensenkop vertoonde. Je zou de pot zo in de uitstalkasten van Costa Rica kunnen plaatsen. Hij vloekte er niet.

Kleinere voorwerpen: fluitjes, als te zien in Costa Rica, bakten onze Karaïben ook. De tegenwoordige Karaïben weten het nog, en noemen ze: 'kio-kio'; ze dienen om konijnen te lokken. Maar of zij ze nog maken kunnen?

Duidelijker verband tussen de Guyana's (Suriname) en MiddenAmerika - vermoed ik - zou kunnen aangetoond worden, indien we door middel van opgravingen maar meer oud, 'pre-columbiaans' materiaal te onzer beschikking hadden. Door opgravingen ook verkrijgt men in Costa Rica de gouden, stenen en keramische produkten. Soms vindt men in de een of andere hoek van het graf een speciaal uit stenen vervaardigde nis, waarin allerlei keramische produkten bijeengebracht zijn: een verzameling van potten, schotels en kleinere voorwerpen van de meest uiteenlopende aard. Doch wij in Suriname zijn met opgravingen maar amper begonnen.

Overeenkomst in elk geval, en ook frappante overeenkomst, vertonen de door Dr. Geijskes opgegraven voorwerpen van de Hertenrits bij Wageningen. Koppen van mens en dier o.a., in klein formaat, met allerscherpste gelaatstrekken delfde hij op. En let nu op de in Costa Rica opgegraven potten of schotels, op die soort schotels nl., die op drie of vier poten staan. Langs heel de Atlantische kust graaft men exemplaren op. Aan de top van deze potten bevindt zich een kleine uitspringende figuur, een 
mensen- of dierenkop voorstellend. Deze figuren insgelijks met allerscherpste gelaatstrekken. De koppen, opgegraven door Dr. Geijskes, en die van Costa Rica gelijken sprekend op elkaar. Onze huidige Indianen boetseren en bakken ze zo niet meer. De oude Indianen kenden en deden het.

Hadden er ook in ons land meer opgravingen plaats gehad, wie weet wat rijk materiaal ter vergelijking naar boven gebracht was! Op hoe grote overeenkomst men wijzen kon!

Interessant is nog, nu ik van schotels en potten spreek, hierbij op te merken, dat de poten van die schotels vaak hol zijn. En in die holte bevindt zich een gebakken bolletje. Je kunt die schotels als 'rammelaar' gebruiken. Kleinere gaten in die poten bevorderen nog de helle klank. Ze doen denken aan de 'karawasi', de dansrammelaar, van onze huidige Indianen: een mandje, waarin zich harde joro-joro-pitten bevinden. Het mandje is bevestigd aan de top van een stok. Al voortstappend stoot men stevig met de stok op de grond en de harde pitten gaan rinkelen. Die schotels met rinkelende poten waren echter praktischer. Twee vliegen in één klap. Je dronk eruit en je danste ermee. En tegelijkertijd bevorderde het een het ander en het ander het een: de drank de dans, de dans de drank.

En hiermee heb ik miin overzicht voltooid, de relatie tussen de Guyana's en Midden-Amerika trachten aan te geven. Wat nu het eerste betreft: overzicht van de opgegraven en tentoongestelde voorwerpen: .... wel een armzalige kijk die ik de lezer op die zeldzame collectie gaf! Voorwerpen, vele ervan, van eeuwen en eeuwen terug! Volgens radio-carbon-onderzoekingen zijn sommige 950 jaar oud. Ik meen zelfs dat de cataloog ergens spreekt van voor Christus' tijd. Voorwerpen van het allerkostbaarste materiaal: goud en edelsteen. Ik zag altijd een drietal flink gewapende politieagenten (militairen?) staan bij de zaal, waarin die sieraden uit goud en edelsteen lagen. Van de allerfijnste, allerkunstzinnigste afwerking! Ik erken tot een betere weergave grif mijn onmacht.

Wat ik nu na de bespreking van de 'vervaardigde' voorwerpen nog wel interessant vind, is ook een woordje te zeggen over de 'gereedschappen en werktuigen' (hoe deftig klinken die woorden!), waarover men beschikken kon. Ik heb dan hierbij niet zozeer de oude volken van Costa Rica op het oog, als wel de Indianen van Suriname. Vooral die, welke zijn uitgestorven: de Wayari- 
koele's, of die nog leven maar totaal van de civilisatie gespeend zijn: de Wama's. Zij mogen dan die dingen gebruikt hebben voor huiselijke doeleinden, voor verzorging van het lichaam of uitoefening van ambachten. Costa Rica bracht ook hier enige opheldering.

De stenen bijl: Ieder kent die. Ook Costa Rica heeft ze. 'Dondersteen' noemt de volksmond ze. 'Dondertand' (konomeru yèrimbo) de Karaĩb. Zo'n bijl komt je niet erg scherp voor. Kun je daarmee werken, vraag je je af. Toch was de stenen bijl die elk der drie mannen (Wama's) in de Oelemari bij zich had, die dus aktueel nog in gebruik is, eer minder scherp dan vele der beneden in ons land gevonden exemplaren. De bijl, d.i. de houten steel met de daarin vastgeklemde steen, heeft de afmeting van onze gewone handbijl. Op twee punten valt onze aandacht: I) de bijl hier in Suriname en ginds in Costa Rica, zijn hetzelfde wat vorm, bewerking en afmeting betreft; 2 ) de voor het leven allernoodzakelijkste bijl leverde in Costa Rica een amulet.

Het mes: De Wamavrouw in de Oelemari gebruikte bij het maken van een drinkbak uit een palmschede (de drinkbak krijgt het voorkomen van een miniatuurbootje) een bamboelatje, aan weerszijden scherp geslepen.

De schaar: Malawni, de laatste der Wayarikoele's, gestorven in r938, zeide: Wij knipten de haren met de tanden van de pireng. De haren vielen tot bijna op de rug en de schouders. Zo wilde het de Wayarikoele-mode. Werden ze langer, dan knipte men. Maar de kinderen huilden, als de operatie geschiedde. Pirengtanden zijn nu eenmaal geen scherpe schaar. Het werktuig werd telkens in houtskoolgruis gedoopt - de vettigheid werd hierdoor van de 'schaar' verwijderd - men blies de houtskool van de 'schaar' af en men knipte verder.

De priem: De benen stekel van de sparri werd op de rotsen verder aangespitst. Een ideale priem! De Wayarikoele-jager gebruikte deze priem o.a. als chirurgisch instrument om er zijn linkerbovenarm mee te openen. Het bloed moest er flink uitspatten. Dan stopte hij in de wond de verkoolde resten van de koenawaroe-kikker. Die kikker maakte hem tot goed jager. Onze pokkeninenting is wel niet zo pijnlijk. Zij met hun inenting - zei Malawni - waren er weken goed mee.

(Mag ik even hierbij opmerken, dat ook in de Karaíbische folklore, dus bij Benedenlandse Indianen de koenawaroekikker een slecht jager tot goed jager maakt. Na de vervanging van het kikkergif door het sterkere oeraligif in de Guyana's, raakte het 
kikkergif in onbruik, maar de idee 'sukses op de jacht door toedoen van de kikker' bleef. Vroeger werkte de kikker op natuurlijke wijze door zijn gif, nu treedt hij op buitennatuurlijke wijze op als magisch bezweringsmiddel).

De beitel: De twee voortanden van het konijn, eerst scherp geslepen op de rotsen, dan door middel van balata, hars en een bindsel bevestigd in een kwattagebeente, deden dienst als beitel.

De rasp: Eertijds een stuk hout of boombast waarin scherpe steentjes zijn bevestigd of een plakkaat gesneden uit de sporen van de iengiprasara. Harde, maar scherpe stekels zitten op die sporen. Aldus zei mij de Wajanahoofdman uit de Litani, Janamale.

De schaaf: Twee soorten schaafinstrumenten had de Indiaan. Voor 'grof' werk diende de pakirakaak. De slagtanden werden krachtig tegen het hout gedrukt, de man haalde de schaaf op en neer en hele repen sneden de tanden weg. Voor 'fijn' werk diende de kaak van het hert. Maar hier schaafden niet de tanden maar de lege tandkassen. Met beide maakten zij o.a. hun bogen.

Ik kom nu bij de boren. Die werktuigen vertonen in hun uiterlijk niets wat op een boor gelijkt, maar ze werken als een boor. Vandaar de naam. Een staaf van been, hout, pijlriet en wie weet van welk ander materiaal nog meer, wordt op de een of andere manier snel rondgedraaid, terwijl terzelfdertijd sterke nederwaartse druk op de staaf uitgeoefend wordt. De staaf 'boort' dus.

De vuur-boor: Onze Wajana's gebruiken tegenwoordig het instrument - vermoed ik - niet meer. Ze wonen te dicht bij de civilisatie. Ze kopen lucifers. Heel wat makkelijker.

Maar in elk geval kennen de Wajana's van de Litani nog het gebruik ervan. Ze deden ons het vuurmaken voor.

Twee mannen zijn er voor nodig, een blok hout waarin een gaatje is, een stuk pijlriet dat juist in het gaatje past.

Een van de mannen begint. Hij plaatst de pijlrietstengel in het gaatje, hij draait de stengel tussen de uitgestoken handen snel heen en weer. Hij begint bovenaan de stengel, daalt geleidelijk naar beneden, terwijl de genoemde beweging met de handen niet onderbroken wordt. Hij drukt hierbij de stengel fors naar omlaag. Voor hij beneden komt, neemt onmiddellijk de tweede voor hem staande man (snel) het snel heen en weerwenden van de stengel over. Ook hij begint bovenaan, werkt naar beneden, daarbij fors drukkend.

Dan weer de eerste man. Om beurten werken ze dus. Er is geen onderbreking in het snel heen en weer wenden van de stengel, in 
EEN BEZOEK AAN HET MUSEUM IN COSTA RicA 59

het 'boren'. Een zeer vermoeiend werk! Het zweet brak hun dan ook uit. Maar binnen enkele minuten zag men rook verschijnen en tenslotte begint de stengel te gloeien en te branden.

De Wama's in de Oelemari zullen de vuurboor nog wel hebben en zo nodig ze gebruiken ook. Ik zeg: zo nodig. Want waar de boor veel inspanning vraagt zorgt men wel - komt het me voor dat men ze maar zelden te gebruiken heeft. 't Zou me niet verwonderen, dat de boor in jaren en jaren niet hoeft op te treden. Elke morgen sleepten de vrouwen massa's hout aan voor het vuur onder de barbakot. Een barbakot van zulke afmeting als beneden bij de Indiaan nooit voorkomt. Elke zijde (de barbakot was driekantig) $2^{1 / 1} / 2$ meter. Ik telde er 30 anjoemarakoppen op. Het vuur is navenant. Verder in de nacht in een en hetzelfde kamp niet minder dan 4 vuren naast de hangmatten. Hun vuren zijn groot en talrijk. In het kamp, sinds vermoedelijk een week verlaten, om verderop het nieuwe kamp te betrekken, waar wij ze aantroffen, smeulde de reuze vuurhoop onder de barbakot nog altijd rustig voort. Hun vuren gaan nooit uit.
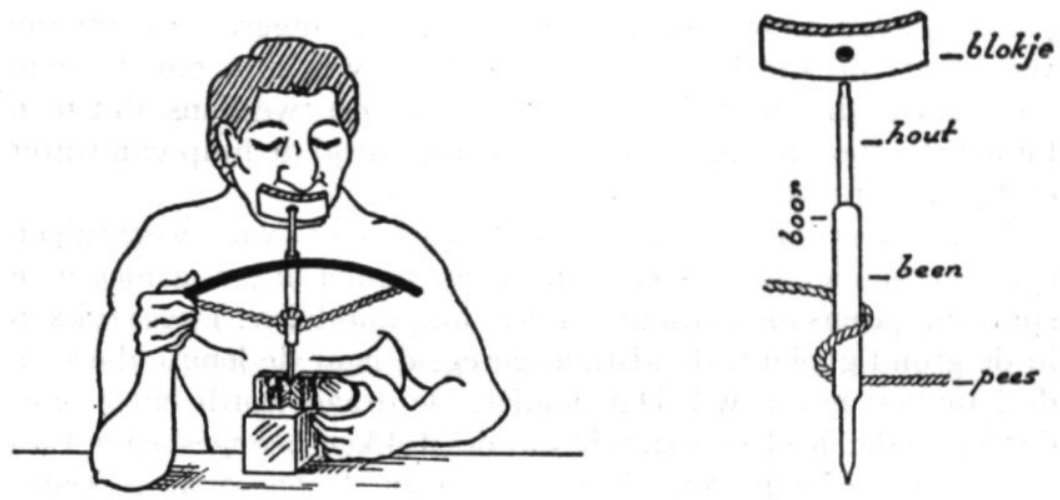

De boog-boor: De heer La Rose heeft de bijgaande duidelijke tekeningen gemaakt. Het instrument heeft het voorkomen van een boog. De benaming is dus al half verklaard. Om het hanteren van dit werktuig duidelijk te kunnen weergeven zal ik het 'boog' blijven noemen. We spreken dan nog van een boog-pees en van de pijl. De pijl, als aanstonds blijken zal, doet dienst als 'boor'. De andere helft van de benaming is dus ook klaar.

Uit welk materiaal bestaat de boogboor?

De boog is van hout, de pees een reep ruwe huid tot een koord gedraaid, de pijl (de boor) voor een derde gedeelte (het kortere 
bovenstuk) van hout ... voor tweederde gedeelte (het langere onderstuk) van been.

Hoe men ermee werkt?

Handen en mond treden op. De boog wordt voor de borst gehouden. De ene hand houdt het te doorboren voorwerp vast, de andere haalt de boog met pees heen en weer. De pees om de pijl (boor) geslingerd doet de pijl (boor) draaien. De pijl staat met haar punt op het te doorboren voorwerp. De werkman buigt voorover en met de mond houdt hij de pijl (de boor) opstaande en ter plaatse, drukt hij deze terzelfdertijd neer. Dit kan de mond natuurlijk niet direct doen, maar het geschiedt via een blokje hout dat tegen de mond gehouden wordt. Dit blokje hout heeft aan de onderkant een holte waarin de boor-top steekt en waarin deze vrij ronddraaien kan.

Terwijl dus de ene hand het te doorboren voorwerp vasthoudt, de andere de boor doet draaien, houdt de mond de boor op het voorwerp. De mond ontwikkele kracht, drukke de boor krachtig neer.

Dan valt nog op te merken, eerstens, dat de benen boor ter plaatse, waar de huiden riem om haar heen slingert, van omvang verandert. $\mathrm{Ze}$ wordt ineens dik. Dit zal wel zijn, om de riem meer vat op het been (de boor) te geven. En tweedens, dat men bij het doorboren van harde voorwerpen altijd de hulp van water en fijn rivierzand of fijn steengruis inriep.

Hangmatvervaardiging: Je kunt hier niet van werktuigen spreken, zonder je de kleine en grote spindel uit, waarmee men spint en garens ineendraait. Andere hulpmiddelen: Twee stokken in de grond geplant, de afstand geregeld naar de lengte die men de hangmat geven wil. Dat is alles. De draad wordt enige honderden malen heel voorzichtig om de stokken heengeslagen. Dan volgen de inslagdraden, de vierlijnen en de hangmat is klaar. De gehele hangmat, zonder je de inslagdraden en de vierlijnen uit, bestaat dus uit één enkele draad, ongeveer I kilometer lang. Primitief? Ja! Toch is de vernuftig gemaakte indiaanse hangmat een sierlijk en praktisch produkt. tieve.

Pottenbakkerij: Hier zijn enkele werktuigen. En zeer primi-

Bij het voorbereiden van het materiaal: een staande en liggende mortier of vijzel, waarin men de gedroogde klei en de verkoolde kwepibast fijnstampt; verder zeven, om elke grofheid uit het materiaal te verwijderen.

Bij het boetseren: een plankje of stukje bast, waarop het voor- 
werp tot de grootste pot toe opgebouwd, geboetseerd wordt, een bamboelatje als mes, een stukje getande kalebasschil om te krabben, een paddestoel om het nog vochtige boetseersel te polijsten. (Een ronde kiezelsteen, de 'takua', polijst later het 'gebakken' voorwerp).

Bij het bakken: Geen oven met liefst regelbare hitte, maar het open vuurtje midden op het plein op een zonnige dag.

Alles tezamen een heel povere installatie. Maar ook hier weer prestaties die er zijn mogen. Er zijn geboren kunstenaressen onder onze Indiaansen. Maar jammer dat er voor haar van geciviliseerde zijde geen verder onderricht in de keramiek bestaat en dat zij, zo die er al was, vermoedelijk er toch geen gebruik van kunnen of willen maken. Nu blijven ze op één en hetzelfde peil, ontwerpen en bakken altijd hetzelfde. Ze moeten het blijven doen met hun open vuurtje, onzeker soms en voor grotere objecten altijd ongeschikt. Het ware te wensen, dat de Indiaanse keramiek, een echt Surinaamse cultuur, in plaats van af te nemen en over enkele jaren uit te sterven, tot grotere ontwikkeling, tot rijker bloei, gebracht kon worden.

Bezoekt men een der pasgebouwde R.K. kerkjes van Lelydorp, of Prins Bernharddorp (spoorbaan), dan zal men aan de wand boven het altaar een groot kruisbeeld zien hangen. Het korpus ca. I meter lang. Ik liet de Karaïbse in Lelydorp een klein kruisbeeld zien. Kun je dit in 't groot maken? Ze deed het. Boetseerde en bakte. Zonder meer.

Ligt hier, op het gebied van beelden bakken - zowel godsdienstige als profane - misschien niet een toekomst voor enkele van onze Indiaanse kunstenaressen?

Na de bespreking van Costa Rica's museum, van zijn oude cultuurvoorwerpen, zal het toch dienstig zijn even te verwijzen naar de opgegraven voorwerpen van VENEZUELA.

Venezuela heeft in de pre-columbiaanse tijd - naar Irving Rouse en José M. Cruxent op het Congres in een voordracht aantoonden - twee verschillende cultuurcentra gehad: een in 't Oosten, een in 't Westen. Elk had zijn eigen gebied, dat het beïnvloedde. De keramiek in ' $t$ Westen was verwant met die van Midden-Amerika en de hoge Andes. Die van het Oosten, het kustgebied, had relatie met de Antillen, de Guyana's en het Amazonegebied.

Maar kent Costa Rica ook niet de indeling: laagland en hoogland ? Ja! Doch enkel geografisch, niet archeologisch.

Vanuit het kustgebied liep een grote weg naar het hoogland. Hele stukken ervan vindt men terug. In zwampgebied opgehoogd. Met bruggen. Sloot aan op de grote heirbaan, lopend van Mexico via de landengte naar Columbia. Er was tussen laagland en hoogland drukke connectie en handel 
en ook wederkerige beïnvloeding op cultureel gebied. Vandaar - als boven reeds gezegd - tref je alle culturen in Linea Vieja (kustgebied) aan; is Linea Vieja een bazaar, is heel de streek een tentoonstellingsgebied.

Niet Costa Rica is het dus waar wij, wanneer we oude voorwerpen vinden, het best ons licht zullen kunnen opsteken, wel Venezuela.

De in Venezuela gevonden voorwerpen zijn radio-carbonisch onderzocht. De tijd van hun ontstaan is bekend. Aan de hand dezer voorwerpen gaat men de ontwikkeling van de keramiek na.

Cruxent onderscheidt 9 typen van keramiek. Voor ons in Suriname zijn van belang de drie typen, die in het Oosten (kustgebied) voorkomen: het Saladoïde, het Barrancoïde en het Aranquinoïde type. Benamingen naar de vindplaatsen.

Naar deze drie typen zullen wij vooral moeten uitzien, willen we al dan niet verwantschap constateren.

Tenslotte wil ik de wens uitspreken, dat de Indiaanse cultuur, zoals zij zich o.a. nog uit in de keramiek, nooit tot het verleden zal behoren - door later-levende mensen enkel in een museum te benaderen-maar dat zij moge voortleven tot in lengte van dagen.

\section{S U M MARY}

\section{A VISIT TO THE MUSEUM OF COSTA RICA}

The author describes his visit to the Museum of Costa Rica, in 1958, where he saw many valuable objects belonging both to the pre-Columbian era and to later periods of Amerindian culture.

He wonders whether the archaeological finds at a site named 'Linea Vieja' and those near Wageningen in Surinam could somehow be related to one another. And he is inclined to answer this question in the affirmative, on the basis of some objects which show a very marked resemblance to those found in Surinam.

While mentioning and describing a few interesting weapons, ornaments, cooking and other utensils, he points out the similarities between them and objects in use in Surinam in former times; for example, use of the 'fire-drill' is still known to the Wajanas of south Surinam. A description, together with a sketch, of the 'bow-drill' is also given.

At the end the author refers to a lecture by Prof. José M. Cruxent, delivered during the 33rd International Americanist Congress at San José (Costa Rica), and thinks that Surinam, in order to understand her past, will have to look at Venezuela, especially the Saladoid, the Barrancoid and the Aranquinoid types of Venezuelan ceramics. 